\title{
Inverter 3 Fasa Menggunakan Metoda Space Vector Pulse Width Modulation (SVPWM)
}

\author{
Muhammad Padri1 ${ }^{1}$ Muldi Yuhendri² \\ 1,2Jurusan Teknik Elektro, Fakultas Teknik, Universitas Negeri Padang \\ Jl. Prof. Dr. Hamka, Air Tawar Padang, 35132, Indonesia \\ mfadri95@gmail.com1‥muldiy@ft.unp.ac.id
}

\begin{abstract}
In the energy industry, many developments have been carried out in order to use environmentally friendly energy such as the use of wind energy and solar energy to produce electrical energy. The power plant is based on electrochemistry where the power generated is still in the form of direct current (DC), so a converter is needed to convert it to Alternating Current (AC). To convert this energy requires a power converter such as a modulated Voltage Source Converter. One of the modulation methods that can be used is Space Vectore Pulse Width Modulation (SVPWM) as in this study. This circuit implements the SVPWM modulation technique for a 3-phase inverter using the ATmega 2560 microcontroller and programmed using matlab simulink. The test results show that the Space Vectore Pulse Width Modulation which is used for the modulation technique produces a 3-phase inverter output and has worked well, but it should be noted that in order to obtain better results it is necessary to develop such a filter to obtain pure sinusoidal waves.
\end{abstract}

Keywords: Inverter; Space Vectore Pulse Width Modulation; ATmega2560

\begin{abstract}
Abstrak- Dalam industri energi banyak dilakukan pengembangan agar bisa menggukan energi yang ramah lingkungan seperti penggunaan energi angin dan energy tenaga surya untuk menghasilkan energi listrik. Pembangkit listrik tersebut berbasis elektrokimia dimana tenaga yand dihasilkan masih dalam bentuk arus searah atau Direct Current (DC), sehingga dibutuhkan sebuah konverter untuk mengubahnya ke Alternating Current (AC). Untuk mengkonversi energi ini dibutuhkan sebuah konverter daya seperti Voltage Source Converter yang dimodulasi. Metode modulasi yang bisa digunakan adalah salah satunya Space Vectore Pulse Width Modulation (SVPWM) seperti pada penelitian ini. Rangkaian ini mengimplementasikan teknik modulasi SVPWM untuk inverter 3 fasa dengan memnggunakan microcontroller ATmega 2560 dan diprogram menggunakan simulink matlab. Hasil pengujian menunjukan bahwa Space Vectore Pulse Width Modulation yang digunakan untuk teknik modulasi menghasilkan output inverter 3 fasa dan telah bekerja dengan baik, namun perlu menjadi catatan untuk memperoleh hasil yang lebih baik perlu dilakukan pengembangan seperti penggunaan filter agar memperoleh gelovang sinusoidal murni.
\end{abstract}

Kata kunci-Inverter; Sapce Vector Pulse Width Modulation; ATmega2560.

\section{PENDAHULUAN}

Salah satu energi yang banyak digunakan manusia untuk memenuhi kebutuhan hidup adalah energi listrik. Pertumbuhan penduduk yang terus meningkat mengakibatkan kebutuhan energy listrik juga meningkat sehingga pemerintah berusaha menmasih perlu dingkatkan jumlah unit pembangkit dan juga menghadirkan pembangkit yang bersumber dari energi terbarukan seperti tenaga surya, tenaga angina, fuell cell, mikrohidro, dan sebagainya. Penggunaan sumber energi terbarukan ini mendapat perhatian karena memiliki kelebihan sebagai sumber energi yang dapat diperbarui, tidak merusak lingkungan dan ketersedian sumbernya yang sangat melimpah. Namun sumber energi terbarukan ini memiliki salah satu kelemahan yakni beberapa sumber energi terbarukan menghasilkan tegangan DC dan beberapa sumber energi terbarukan menghasilkan tegangan AC namun belum stabil sehingga dibutuhkan sebuah converter daya. Untuk mengubah tegangan DC menjadi AC dibutuh konverter untuk mengkonversinya. Konverter DC ke AC dikenal sebagai inverter yang mengubah tegangan input berupa tegangan DC menjadi output tegangan AC dengan frekuensi dan tegangan yang bisa diatur. Untuk mengatur output bisa dengan memvariasikan tegangan input DC, namun jika teganngan input tidak dapat dikontrol maka bisa memvariasikan gain inverter, yang biasanya dilakukan dengan sistem Pulse Width Modulation (PWM)[1]. Sistem PWM ini dimaksud untuk memodulasi switch inverter.

Modulasi switch inverter dilakukan dengan metode switching pada frekuensi tertentu. Switching merupakan proses perpindahan kondisi ON ke OFF atau sebaliknya. 
Lama perpindahan ON ke OFF atau sebaliknya bisa diatur dan ini mempengaruhi besar tegangan keluaran, proses ini disebut teknik pelebaran pulsa modulasi atau Pulse Width Modulation (PWM). Untuk inverter ada beberapa metode PWM yang telah diterapkan, diantaranya metode konduksi $180^{\circ}$, metode Sinusoidal Pulse Width Modulation (SPWM) dan metode Space Vector Pulse Width Modulation (SVPWM), Selected Harmonic Elimination Pulse Width Modulation (SHEPWM) dan Hysterisis Current Control Pulse Width Modulation (HCCPWM)[2]. Metode SVPWM dan SHEPWM harus meliki tegangan feedback untuk modulasinya dan juga membutuhkan algoritma yang cukup rumit. Metode SVPWM lebih unggul dikarenakan menghasilkan tegngan dengan harmonic. yang lebih kecil dan indeks modulasi amplitude yang lebih besar serta bisa diterapkan dalam konsep digital[3]-[4].

\section{METODE}

Penelitian ini dilakukan dalam bentuk eksperimen yang dimulai dengan perancangan, pembuatan dan penguji menggunakan Simulink matlab.

\section{Inverter 3Phase}

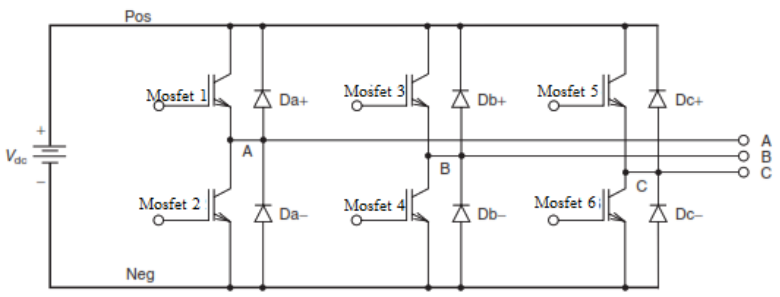

Gambar 1. Rangkaian Inverter 3Phase[5]

Inverter digunakan untuk membuat tegangan AC dari suplai DC. Di kelas inverter polyphase, inverter tiga fasa adalah inverter yang paling banyak digunakan dan dikembangkan. Sejumlah besar inverter digunakan untuk motor penggerak kecepatan yang dapat diatur. Inverter yang digunakan pada aplikasi ini adalah inverter dengan sumber tegangan menggunaka hard-switched yang menghasilkan sinyal Pulse Width Modulation (PWM) dengan dasar sinusoidal. Selain inverter hard-switched yang sangat umum, penelitian yang sedang dilakukan pada teknik soft-switching. Inverter switched menggunakan semikonduktor daya yang dapat dikontrol untuk menghubungkan terminal output ke bus DC yang stabil. Di sisi lain, inverter soft-switching memiliki rangkaian intermediate yang berosilasi dan mencoba membuka dan menutup saklar daya di bawah kondisi nol volt dan atau zero-current [5]

\section{Mosfet}

MOSFET singkatan dari Metal Oxide Semiconductor Field Effect Transistor merupakan komponen semi kondukto yang dapat digunakan sebagai saklar elektromagnetik dan penguat sinyal pada perangkat elektronik. Umumnya MOSFET nemiliki tiga kaki yakni gate (G), drain (D) dan Source (S). Perangkat ini adalah semikonduktor yang membutuhkan penggerak tegangan konstan dari kaki gate dan sepenuhnya dikendalikan di terminal gate dalam kondisi operasi normal. Perangkat ini tidak menghalangi konduksi, dan karena itu tidak memerlukan sirkuit khusus[2]. Gerbang MOSFET diisolasi secara elektrik dari sumbernya oleh lapisan silikon oksida. Gerbang menarik hanya satu menit kebocoran arus pada urutan nanoampere. Oleh karena itu, rangkaian penggerak pada gate sederhana dan rugi daya pada rangkaian kendali gate dapat diabaikan. Kapasitansi gate ke source dan gate je drain harus diisi dan dikosongkan dengan tepat untuk mendapatkan kecepatan switching yang diinginkan, dan rangkaian penggerak harus memiliki impedansi keluaran yang cukup rendah untuk memasok arus pengisian dan pengosongan yang diperlukan[6].

MOSFET mempunyai sumber gerbang dan penguras. Berbeda dengan JFET, gerbang diisolasikan dari saluran. Oleh karena itu, arus gerbang menjadi amat kecil. Hal ini tidak dipengaruhi oleh positif atau negatifnya gerbang itu. MOSFET kadang-kadang disebut IGFET (insulated-gate FET atau gerbang terisolasi)[7]. MOSFET secara inheren mampu beroperasi pada frekuensi tinggi. Tapi tetap saja MOSFET memiliki keterbatasan pada kapasitansi gerbang input tinggi dan Transient/delay karena transport carrier melalui daerah drift[8].

\section{Space Vector Pulse Width Modulation (SVPWM)}

Space Vector Pulse Width Modulation (SVPWM) adalah salah satu dari beberapa teknik Voltage Source Inverter (VSI). SVPWM merupakan teknik modulasi yang mampu menghasilka gelombang tegangan sinus yang lebih baik. SVPWM memiliki beberapa keunggulan seperti mengurangi kerugia switching distorsi harmonic lebih kecil dibandingakan SPWM dan kompatibel untuk implementasi digital[9].

Teknik modulasi SVPWM menggunakan space vector yang menghasilkan tegangan referensi untuk VSI. Space vector merepresentasikan magnitudo dan sudut fasa 3 fasa simetri sebagai fungsi waktu. Salah satu pendekatan modulasi yang paling populer untuk two-level converters adalah space vector pulse width modulation (SVPWM), yang semakin sering digunakan dalam kontrol konverter bertingkat. Ini adalah teknik PWM intensif dan komputasiintensif. SVPWM meningkatkan kemampuan output dari 
PWM sinusoidal tanpa distorsi gelombang tegangan output line-to-line. Keuntungan dari SVPWM adalah kontrol sesaat dari keadaan switching. Selain itu, tegangan output dengan hampir semua nilai rata-rata menggunakan tiga vektor terdekat, yang merupakan metode yang menghasilkan kinerja spektral terbaik. Karena karakteristik kinerja yang unggul, telah menemukan aplikasi yang tersebar luas dalam beberapa tahun terakhir. Jika frekuensi switching cukup tinggi, kerugian karena harmonik dapat hampir terabaikan, dan SVPWM adalah solusi yang lebih baik dalam hal tegangan output inverter, kerugian harmonic[10].

Pada sistem 3 fasa seimbang, persamaan vektor dari jumlah tegangan dapat dinyatakan dengan persamaan berikut:

$\bar{v}=\frac{2}{3}\left[v_{a}(t)+a v_{b}(t)+a^{2} v_{c}(t)\right]$

Dengan,

$v_{a}(t)=v_{m} \sin (\omega t)$

$v_{b}(t)=v_{m} \sin \left(\omega t-120^{\circ}\right)$

$v_{c}(t)=v_{m} \sin \left(\omega t+120^{\circ}\right)$

$a=e^{j \frac{2 \pi}{3}}=\cos \left(\frac{2 \pi}{3}\right)+j \sin \left(\frac{2 \pi}{3}\right)$

$a^{2}=e^{j \frac{4 \pi}{3}}=\cos \left(\frac{4 \pi}{3}\right)+j \sin \left(\frac{4 \pi}{3}\right)$

Vektor tegangan pada VSI dapat dirumuskan seperti persamaan berikut:

$\bar{v}=\frac{2}{3} V_{d c}\left[S_{1}+a S_{3}+a^{2} S_{5}\right]$

Vektor tegangan output $\bar{V}_{o}$ ditentukan oleh tegangan referensi $V_{\alpha o}$ dan $V_{\beta o}$ yang didapat dari output kontroller kecepatan. Dari tegangan referensi $V_{\alpha o}$ dan $V_{\beta o}$ bisa dihitung magnitudo $V_{o m}$ dan sudut vektor tegangan $\theta_{o}$ dengan persamaan:

$V_{o m}=\sqrt{V_{\alpha o}^{2}+V_{\beta o}^{2}} \operatorname{dan} \theta_{o}=\operatorname{atan} \frac{V_{\beta o}}{V_{\alpha o}}$

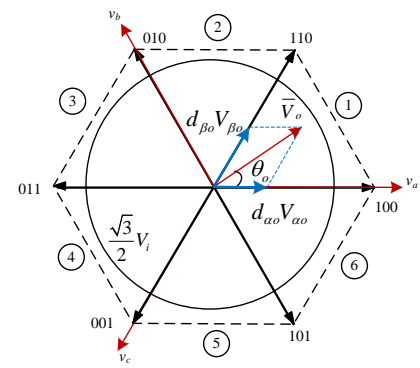

Gambar 2. Vektor tegangan output [11]

Berdasarkan Gambar 2, vektor tegangan output $\bar{V}_{o}$ dapat dirumuskan dengan persamaan berikut:

$\overline{V_{o}}=d_{\alpha o} V_{\alpha o}+d_{\beta o} V_{\beta o}$

$d_{\alpha o}$ dan $d_{\beta o}$ adalah duty cycle switch VSI dalam sumbu $\alpha \beta$. Duty cycle dapat dihitung dengan persamaan berikut: $d_{\alpha o}=m_{o} \sin \left(\frac{\pi}{3}-\theta_{o}\right)$

$d_{\beta o}=m_{o} \sin \left(\frac{\pi}{3}\right)$

$d_{0 o}=1-d_{\alpha o}-d_{\beta o}$

Dengan,

$m_{o}=\frac{\sqrt{3} V_{o m}}{V_{p n}}, 0 \leq m_{o} \leq 1$

$m_{o}$ merupakan indeks modulasi VSI. Agar lebih mudah dalam penentuan switch yang aktif, maka vektor tegangan output dibagi menjadi enam sektor, seperti yang dapat dilihat pada Gambar 2. Masig-masing sektor dibatasi oleh sudut vektor tegangan, seperti yang terlihat pada persamaan berikut :

$m=\left\{\begin{array}{ccc}1 & j i k a & 0 \leq \theta \leq \frac{\pi}{3} \\ 2 & j i k a & \frac{\pi}{3} \leq \theta \leq \frac{2 \pi}{3} \\ 3 & j i k a & \frac{2 \pi}{3} \leq \theta \leq \pi \\ 4 & j i k a & \pi \leq \theta \leq \frac{4 \pi}{3} \\ 5 & j i k a & \frac{4 \pi}{3} \leq \theta \leq \frac{5 \pi}{3} \\ 6 & j i k a & \frac{5 \pi}{3} \leq \theta \leq 2 \pi\end{array}\right.$

Tegangan referensi untuk inverter dapat dihitung setelah sektor dan vektor tegangan diketahui. Gambar 2 memperlihatkan pembagian sektor dan vektor tegangan inverter. Dari Gambar 2 dapat di lihat bahwa tegangan referensi $V_{S}$ merupakan penjumlah dari vektor tegangan $V_{1}$ dan $V_{2}$ yang besarnya dipengaruhi oleh perioda masing-masing.

Dari Gambar 2 didapatkan persamaan tegangan referensi pada sektor 1 , yaitu :

$V_{S}=V_{\alpha}+V_{\beta}$

$V_{S}=\frac{T_{1}}{T_{s}} V_{1}+\frac{T_{2}}{T_{s}} V_{2}$

Pada Gambar 3 juga terdapat $V_{0}$ pada titik 0 dengan waktu $T_{0}$. Bila $T_{1}$ adalah waktu untuk vektor tegangan ke$\mathrm{k}$ dan $T_{2}$ adalah waktu untuk vektor tegangan ke-k+1, maka dapat dituliskan dalam bentuk persamaan :

$T_{k}=\frac{T \sqrt{3}}{V_{d c}}\left[v_{\alpha} \sin \left(\frac{k \pi}{3}\right)-v_{\beta} \sin \left(\frac{k \pi}{3}\right)\right]$ 


$$
\begin{aligned}
& T_{k+1}=\frac{T \sqrt{3}}{V_{d c}}\left[v_{\beta} \cos \left(\frac{(k-1) \pi}{3}\right)-v_{\alpha} \cos \left(\frac{(k-1) \pi}{3}\right)\right] \\
& T_{0}=T-T_{k}-T_{k+1}
\end{aligned}
$$

Berdasarkan persamaan tersebut dapat kita tentukan persamaan umum tegangan referensi pada setiap sektor. Bila $V_{1}$ adalah vektor tegangan ke-k dan $V_{2}$ adalah vektor tegangan ke-k+1 maka persamaan umum tegangan referensi adalah :

$V_{S}=d_{k} V_{k}+d_{k+1} V_{k+1}$

$d_{k}$ merupakan duty cycle vektor tegangan ke-k dan $d_{k+1}$ adalah duty cycle vektor tegangan $\mathrm{ke}-\mathrm{k}+1$. Duty cycle merupakan perbandingan antara waktu ON dan OFF sebuah saklar dengan perioda sampling tertentu, seperti yang dapat dilihat dari persamaan berikut:

$d_{k}=\frac{T_{k}}{T_{s}}$

$$
\text { dan } d_{k+1}=\frac{T_{k+1}}{T_{s}}
$$

duty cycle vektor tegangan ke-k dan ke-k+1 pada setiap sektor ditunjukkan dalam Tabel 1.

\begin{tabular}{|c|c|c|c|}
\hline Sektor $(m)$ & $\theta$ & $d_{k}$ & $d_{k+1}$ \\
\hline 1 & $0 \leq \theta \leq \frac{\pi}{3}$ & $\frac{2}{\sqrt{3}} \frac{V_{S}}{V_{d c}} \sin \left(\frac{\pi}{3}-\theta\right)$ & $\frac{2}{\sqrt{3}} \frac{V_{S}}{V_{d c}} \sin (\theta)$ \\
\hline 2 & $\frac{\pi}{3} \leq \theta \leq \frac{2 \pi}{3}$ & $\frac{2}{\sqrt{3}} \frac{V_{S}}{V_{d c}} \sin \left(\frac{\pi}{3}+\theta\right)$ & $\frac{2}{\sqrt{3}} \frac{V_{S}}{V_{d x}} \sin \left(\frac{5 \pi}{3}+\theta\right)$ \\
\hline 3 & $\frac{2 \pi}{3} \leq \theta \leq \pi$ & $\frac{2}{\sqrt{3}} \frac{V_{S}}{V_{d x}} \sin (\theta)$ & $\frac{2}{\sqrt{3}} \frac{V_{S}}{V_{\alpha c}} \sin \left(\frac{4 \pi}{3}+\theta\right)$ \\
\hline 4 & $\pi \leq \theta \leq \frac{4 \pi}{3}$ & $\frac{2}{\sqrt{3}} \frac{V_{s}}{V_{d k}} \sin \left(\frac{5 \pi}{3}+\theta\right)$ & $\frac{2}{\sqrt{3}} \frac{V_{S}}{V_{\alpha c}} \sin (2 \pi-\theta)$ \\
\hline 5 & $\frac{4 \pi}{3} \leq \theta \leq \frac{5 \pi}{3}$ & $\frac{2}{\sqrt{3}} \frac{V_{S}}{V_{d c}} \sin \left(\frac{4 \pi}{3}+\theta\right)$ & $\frac{2}{\sqrt{3}} \frac{V_{S}}{V_{d c}} \sin \left(\frac{2 \pi}{3}+\theta\right)$ \\
\hline 6 & $\frac{5 \pi}{3} \leq \theta \leq 2 \pi$ & $\frac{2}{\sqrt{3}} \frac{V_{S}}{V_{d c}} \sin (2 \pi-\theta)$ & $\frac{2}{\sqrt{3}} \frac{V_{S}}{V_{d c}} \sin \left(\frac{\pi}{3}+\theta\right)$ \\
\hline
\end{tabular}

Tabel 1. Duty cycle vektor tegangan ke-k dan ke-k+1 pada setiap sektor

Dari persamaan sebelumnya juga dapat ditentukan waktu switching masing-masing saklar inverter pada setiap sector.

Tabel 2. Waktu switching pada masing saklar setiap

\begin{tabular}{|c|c|c|}
\hline & $\begin{array}{l}S_{3}=T_{k+1}+\frac{T_{0}}{2} \\
S_{5}=\frac{T_{0}}{2}\end{array}$ & $\begin{array}{l}S_{4}=T_{k}+\frac{T_{0}}{2} \\
S_{6}=T_{k}+T_{k+1}+\frac{T_{0}}{2}\end{array}$ \\
\hline 2 & $\begin{array}{l}S_{1}=T_{k}+\frac{T_{0}}{2} \\
S_{3}=T_{k}+T_{k+1}+\frac{T_{0}}{2} \\
S_{5}=\frac{T_{0}}{2}\end{array}$ & $\begin{array}{l}S_{2}=T_{k+1}+\frac{T_{0}}{2} \\
S_{4}=\frac{T_{0}}{2} \\
S_{6}=T_{k}+T_{k+1}+\frac{T_{0}}{2}\end{array}$ \\
\hline 3 & $\begin{array}{l}S_{1}=\frac{T_{0}}{2} \\
S_{3}=T_{k}+T_{k+1}+\frac{T_{0}}{2} \\
S_{5}=T_{k+1}+\frac{T_{0}}{2}\end{array}$ & $\begin{array}{l}S_{2}=T_{k}+T_{k+1}+\frac{T_{0}}{2} \\
S_{4}=\frac{T_{0}}{2} \\
S_{6}=T_{k}+\frac{T_{0}}{2}\end{array}$ \\
\hline 4 & $\begin{array}{l}S_{1}=\frac{T_{0}}{2} \\
S_{3}=T_{k}+\frac{T_{0}}{2} \\
S_{5}=T_{k}+T_{k+1}+\frac{T_{0}}{2}\end{array}$ & $\begin{array}{l}S_{2}=T_{k}+T_{k+1}+\frac{T_{0}}{2} \\
S_{4}=T_{k+1}+\frac{T_{0}}{2} \\
S_{6}=\frac{T_{0}}{2}\end{array}$ \\
\hline 5 & $\begin{array}{l}S_{1}=T_{k+1}+\frac{T_{0}}{2} \\
S_{3}=\frac{T_{0}}{2} \\
S_{5}=T_{k}+T_{k+1}+\frac{T_{0}}{2}\end{array}$ & $\begin{array}{l}S_{2}=T_{k}+\frac{T_{0}}{2} \\
S_{4}=T_{k}+T_{k+1}+\frac{T_{0}}{2} \\
S_{6}=\frac{T_{0}}{2}\end{array}$ \\
\hline 6 & $\begin{array}{l}S_{1}=T_{k}+T_{k+1}+\frac{T_{0}}{2} \\
S_{3}=\frac{T_{0}}{2} \\
S_{5}=T_{k}+\frac{T_{0}}{2}\end{array}$ & $\begin{array}{l}S_{2}=\frac{T_{0}}{2} \\
S_{4}=T_{k}+T_{k+1}+\frac{T_{0}}{2} \\
S_{6}=T_{k+1}+\frac{T_{0}}{2}\end{array}$ \\
\hline
\end{tabular}
sector

\begin{tabular}{|l|l|l|}
\hline $\begin{array}{l}\text { Sektor } \\
(m)\end{array}$ & Saklar Atas & Saklar bawah \\
\hline 1 & $S_{1}=T_{k}+T_{k+1}+\frac{T_{0}}{2}$ & $S_{2}=\frac{T_{0}}{2}$ \\
\hline
\end{tabular}

Dari Tabel 2 tersebut kita bisat menggambarkan pulsa switching masing-masing saklar. Gambar 3 menunjukkan pulsa switching pada sektor 1 dalam satu perioda sampling[12]. 


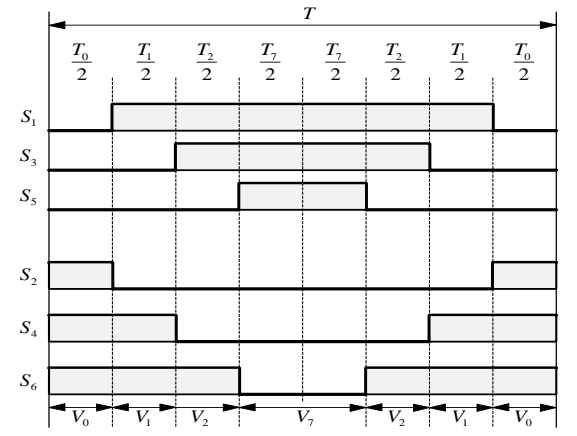

Gambar 3. Pulsa switching pada sektor 1[12]

\section{ATmega 2560}

Board Arduino Mega 2560 merupkan sebuah arduino dengan IC microcontroller ATmega 2560. Arduino Mega 2560 memiliki 54 digital input/ output dimana 15 buah diantaranya dapat digunakan untuk output PWM, 16 buah analog input, 4 universatl asynchronous receiver/ transmitter (UARTs), osilator Kristal 16 MHz, koneksi USB, jack power, dan soket In-Circuit System Programing (ICSP) serta tombol reset[13].

\section{Simulink Matlab}

Simulink merupakan sebuah modul dari matlab yang bias digunakan untuk mensimulasikan system dinamik dengan cara grafis berbentuk digram blok, sistem dinamik dapat dimodelkan dengan diagram blok sistem sinyal, summing junction, block gain, source dan sink.[14]

Pada Simulink matlab telah menyediakan komponen untuk mempermudah dalam mendesain tampilan program. Sehingga dalam penulisan program tidak diperlukan lagi dalam penulisan kode untuk membuat tampilannya. Tampilan di dalam Simulink Matlab dapat diatur dengan cara mengambil tools yang akan dipakai pada form yang sudah tersedia[15].

\section{Block Diagram}

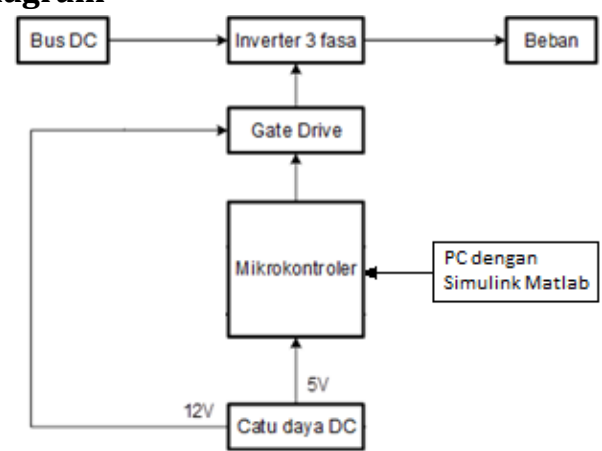

Gambar 4. Blok Diagram Inverter 3 Fasa

Pada penelitian ini dapat dilihat melalui blok diagram diatas bahwa sumber tegangan DC yang masuk ke inverter akan diubah menjadi output inverter 3 fasa yang dihubungkan ke beban. Teknik modulasi yang digunakan yaitu inverter dengan metoda SVPWM. Tekni modulasi ini menggunakan mikrokontroler ATmega2560 yang diprogram melalui komputer dengan aplikasi simulink matlab.

Catu daya 5 volt digunakan sebagai sumber tegangan mikrokontroler ATmega 2560 dana catu daya $12 \mathrm{~V}$ akan digunakan sebagai sumber tegangan hight dan low pada rangkaian gate drive. Sinyal keluaran arduino ATmega 2560 akan terhubung ke gate drive melaui masing-masing pin hight dan low yang keluarnya akan diteruskan ke rangkaian inveter.

\section{HASIL DAN PEMBAHASAN}

Alat voltage source converter berupa inverter tiga fasa yang telah dirangkai terdiri atas rangakaian catu daya, mikrokontroler, gate drive, rangkaian inver, dihubungkan dengan beban resistor dan sumber diambil dari sumber DC yang dihubungkan lansung ke rangkaian Iverter sebagai input tegangan. Mikrokontroler yang digunakan berupa arduino ATmega2560 dimana mikrokontroler ini diprogram dari aplikasi simulink matlab melalui PC. Setelah dilakukan pembuatan program selanjutnya dilakukan pengujian alat untuk melihat keluaran inverter dan keluaran ardino berupa grafik yang bias dilihat melalui osiloskop dan simulink matlab. Untuk pengujian alat sumber DC menggunakan power pack, untuk beban menggunakan load resistor 3fasa. Berikut foto pengujian alat

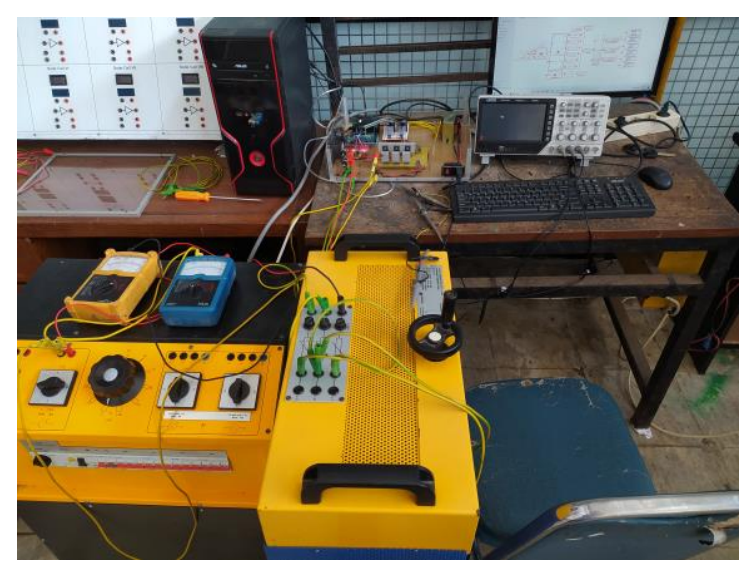

Gambar 5. Pengujian Alat

\section{Pengujian Pada Simulink Matlab}

Pada pengujian simulink, berikut block program pada simulink matlab, 


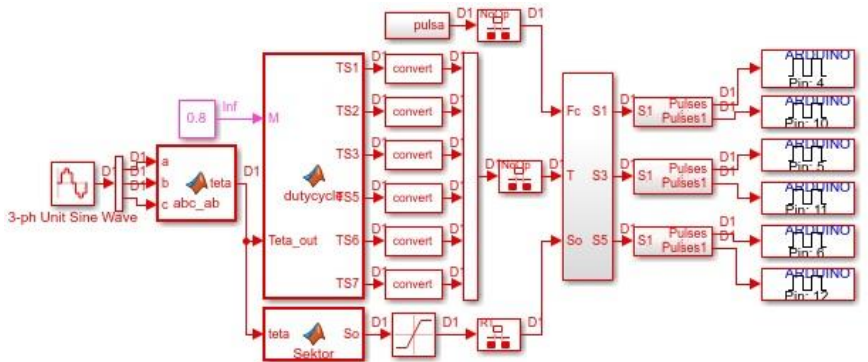

Gambar 7. Program pada Simulink Matlab

Program diatas merupakan blok program untuk modulasi inverter dengan metode SVPWM yang teridiri atas beberapa fuction block dan output. Blocknya teridir dari 3ph sine wave yang merupakan tegangan refferensi, block konversi abc ke alfa beta, block konversi alfa dan indeks modulasi ke duty cycle, blok konversi beta ke sector, block menentukan switching mosfet, dan output pin arduino untuk hight side inverter pada pin 4,5 dan 6 sedangkan pada low side inverter pada pin 10,11 dan 12.

Berikut bentuk gelombang tegangan refferensi 3fasa, Modulasi Indeks dan Sektor.

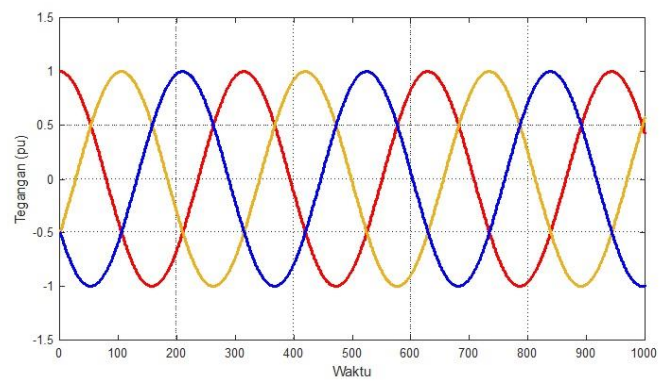

Gambar 8. Tegangan Refferensi

Tegangan refferensi 3 fasa digunakan untuk memporelah nilai abc untuk dikonfersikan menjadi alfa dan beta. Kemudian nilai alfa dapat digunaka untuk menentukan sector sudut/ teta.

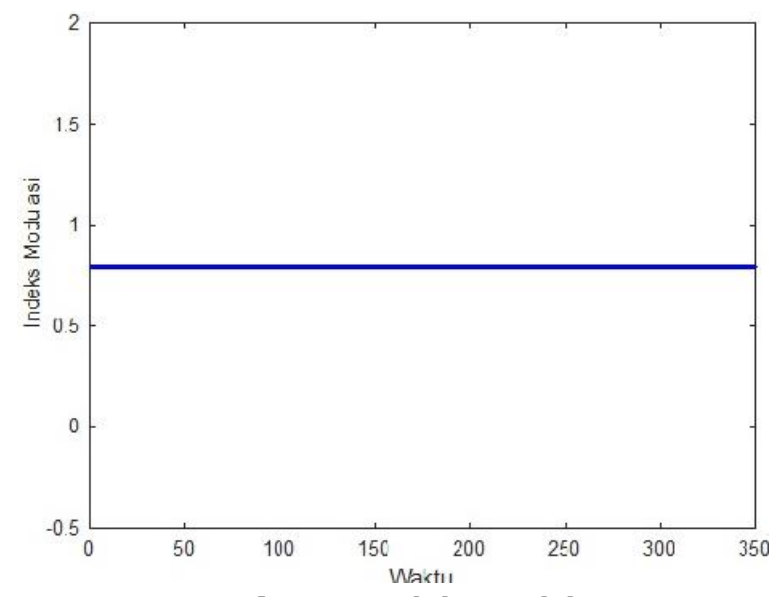

Gambar 9. Modulasi Indeks
Modulasi indeks disini yang digunakan berupa nilai konstan, nantinya nilai indeks dan nilai teta yang didapat sebelumnya akan diprogram untuk memperoleh time switching/ duty cycle.

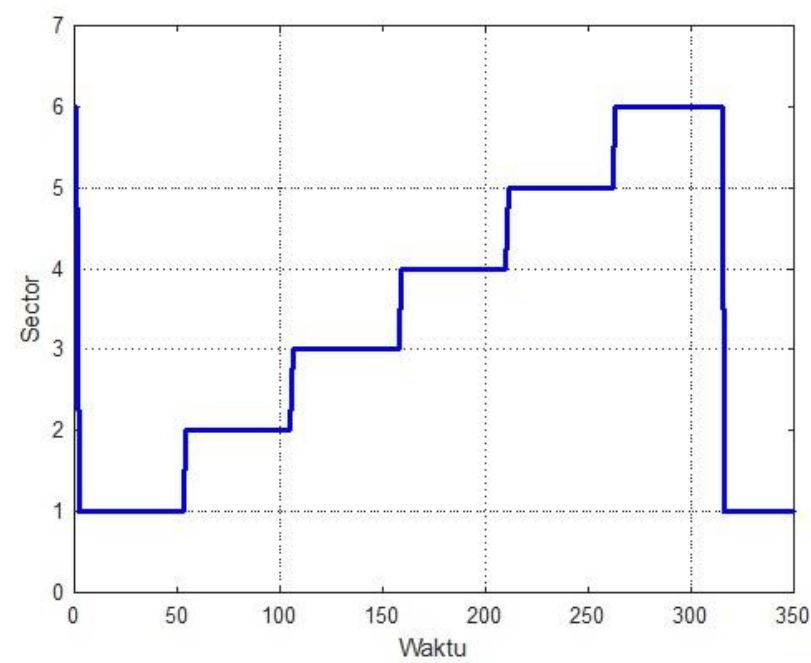

Gambar 10. Sektor

Selain untuk meperoleh nilai duty cycle nilai teta juga bias digunakan untuk menentukan sector melalui pemograman arduino. Dalam metode SVPWM ini akan diperoleh 6 sektor untuk mempermudah penentuan switch yang aktif.

\section{Pengujian Output Arduino}

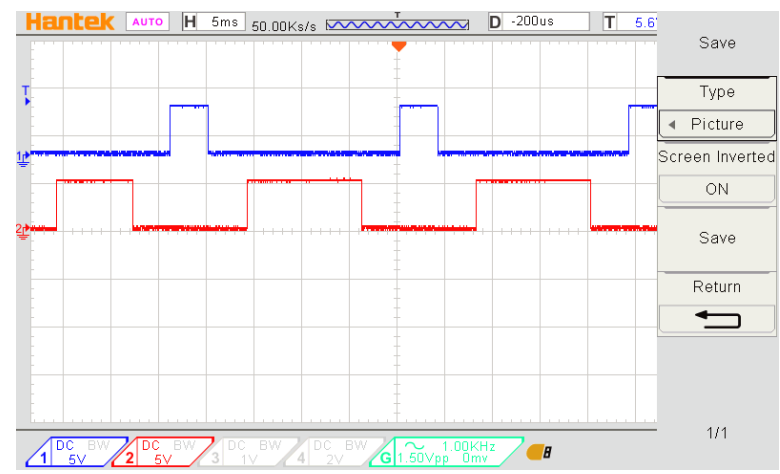

Gambar 11. Gelombang Keluaran Arduino

Pengujian keluaran arduino dilakukan untuk memastikan keluarannya sesusai dengan yang seharusnya. Berdasarkan gelombang keluaran arduino pada gambar 11 dapat dilihat bahwa antara fasa 1 dan fasa 2 tidak ada dalam kondisi hight secara bersamaan. Kondisi ini diharuskan karena jika fasa 1 dan 2 dalam kondisi hight secara bersamaan akan merusak rangkaian gate drive. 


\section{Pengujian Output Inverter}

Pengujian output inverter dilakukan untuk mengetahui hasil dari keluaran alat. Berdasarkan hasil pengujian dengan masukan tegangan 12 Volt DC dan menggunakan beban resistor keluaran yang diperoleh adalah \pm 6 Volt AC dengan bentuk gelombang sebagai berikut,

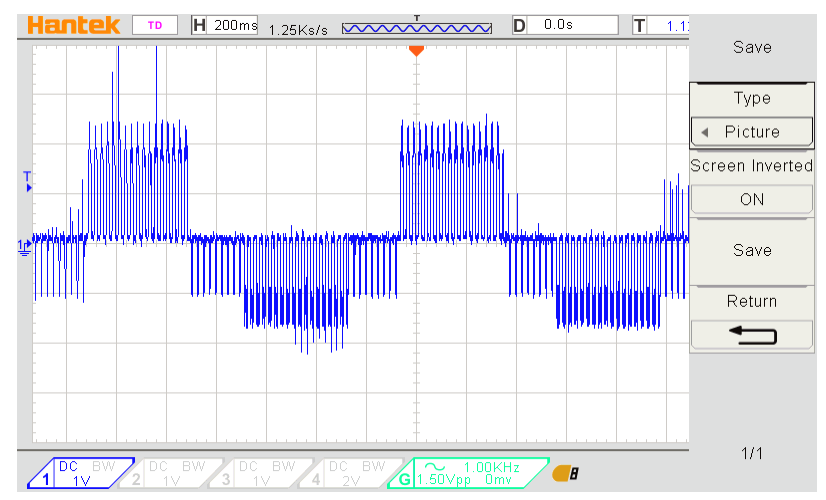

Gambar 12. Gelombang Output Fasa-Netral

Gambar 12 merupakan bentuk gelombang output fasa netral dari inverter yang dimodulasi dengan metode SVPWM. Gelombang ini didapat dari output hardware menggunakan beban resistor menggunakan alat uji osilosope.

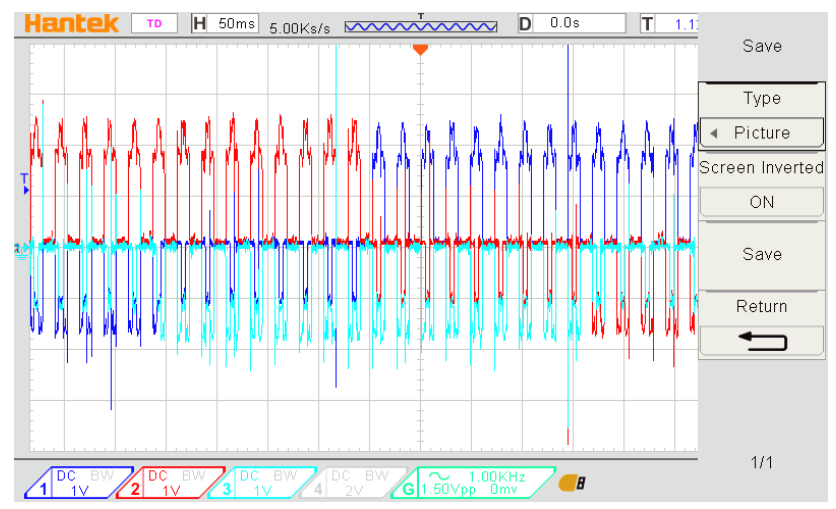

\section{Gambar 13. Gelobang Output 3 Fasa}

Gambar 13 merupakan bentuk gelombang output masing-masing fasa dari inverter yang dimodulasi dengan metode SVPWM. Gelombang ini didapat dari output hardware menggunakan beban resistor menggunakan alat uji osilosope.

\section{KESIMPULAN}

Berdasarkan hasil pengujian penggunaan metoda Space Vector Pulse Width Modulation (SVPWM) untuk memodulasi inverter dengan pengimplementasian mikrokontroler ATmega 2560 sebagai control yang diprogram melalui simulink matlab telah bekerja dengan baik. Dimana alat mampu mengubah input tegangan DC menjadi ouput tegangan $\mathrm{AC}$ dengan menggunakan metode SVPWM tersebut. Namun untuk memperoleh gelombang keluaran yang lebih baik berupa sinusoidal murni perlu ditambahkan filter pada output alat sebagai pengembangan lebih lanjut.

\section{DAFTAR KEPUSTAKAAN}

[1] Patil, dkk. "Implementation of SVPWM Based Three Phase Inverter Using 8 Bit Microcontroller". IJSETR: Vol 4 No. 6, 2015.

[2] Muhammad, Rashid. "Power Electronics Handboock". Florida: Butterworth Heineman, 2011.

[3] Dolly, Raney. "Modeling and Simulation of PWM Inverter" IEE: 978-1-4344-9190-2. 2011.

[4] I, Nyoman, Wahyu, Setiawan, dkk. "Perbandingan Kinerja Teknik Modulasi Inverter Du-Level untuk Pengaturan Kecepatan Motor Induksi Tiga -Fase". eJAEI: Vol 1 No. 1, 2015.

[5] Leonard L. Grigsby. "Electric Power Engineering Handbook - Power System" New York: CRC Press. 2017.

[6] Leonard L Grigsby. "PowerSystem". New York: CRC Press 2007.

[7] Albert, Paul, Malvino. "Prinsip-Prinsip Elektronika". Jakarta: Erlangga. 1999.

[8] S, Allirani, V,B, Thurai, Raaj. "Development of Sapcave Vector Piulse Width Modulation Algorithm for Voltage Source Inverter Using dsPIC Controller 30F4011". IJPAM: Vol 114 No 9. 2017

[9] Muhammad Rashid. "Power Electronics Handboock". Florida: Butterworth Heineman. 2017.

[10] Satish, Kumar, Peddapelli. (2017). "Pulse Width Modulation - Analysis And performance In Multilevel Inverters". Boston: De Gruyter.

[11] Muldi, Yuhendri, M. Ashari, M.H. Purnomo. "Adaptive Type-2 Fuzzy Sliding Mode Control for Grid-Connected Wing Turbine Generator Using Very Sparse Matrix Converter" IJoRER: Vol 5 No 3. 2015.

[12] K Vinoth, Kumar, dkk. "Simulation And Comparison of SPWM Anda SVPWM Control FFor Three Phase Inverter". ARPN: Vol 5 No 7. 2010.

[13] Andriyanto, Heri dan Aan, Darmawan. (2016). "Arduino Belajar Cepat dan Pemrograman". Bandung: Informatika Bandung.

[14] Safarudin, M. "Pengenalan Matlab dan Simulink". Program Studi Teknik Mesin Sekolah Tinggi TeknologiMandala. 2015 
[15] Priatmoko, Andi. Harahap, Erwin. "Implementasi Algoritma Des Menggunakan Matlab". Jurnal Matematika 16(1). 2017

\section{Biodata Penulis}

Muhammad Padri, lahir di Bukittinggi tangal 13 Desember 1995. Menyelesaikan program studi DIV Teknik Elektro Industri pada Jurusan Teknik Elektro Universitas Negeri Padang pada tahun 2019.

Dr. Muldi Yuhendri, S.Pd, M.T, lahir di Kampung Aur tanggal 13 Desember 1981, menyelesaikan S1 Pendidikan Teknik Elektro di Universitas Negeri Padang pada tahun 2005, menyelesaikan S2 Teknik Elektro Sistem Tenaga di Institut Teknologi Sepuluh Nopember (ITS) pada tahun 2007, dan menyelesaikan S3 Ilmu Teknik Elektro di Institut Teknologi Sepuluh Nopember (ITS) pada tahun 2010. Staff pengajar pada jurusan Teknik Elektro Fakultas Teknik Universitas Negeri Padang hingga sekarang 